\title{
Phytophthora infestans Produces Oospores in Fruits and Seeds of Tomato
}

\author{
Evgenia Rubin, Alexander Baider, and Yigal Cohen
}

Faculty of Life Sciences, Bar-Ilan University, Ramat-Gan 52900, Israel.

Accepted for publication 23 July 2001.

\section{ABSTRACT}

Rubin, E., Baider, A., and Cohen, Y. 2001. Phytophthora infestans produces oospores in fruits and seeds of tomato. Phytopathology 91:10741080 .

Tomato fruits at the mature green stage coinoculated with $\mathrm{A} 1+\mathrm{A} 2$ sporangia of Phytophthora infestans, the late blight causal fungus, showed abundant oospores in the vascular tissues, pericarp, columella, and placenta. Oospores were also formed on the surface of fruits kept in moisture-saturated atmosphere. Occasionally, oospores were enclosed between the epidermal hairs of the seed coat. In a few seeds, oospores were detected inside the embryo. The data suggest that blighted tomato fruits may carry a large number of oospores, thus making them a threatening source of blight inoculum. Such fruits may also release airborne oosporic inoculum that may introduce recombinant genotypes within a growing season. Although Phytophthora infestans is seedborne in tomato, to our knowledge, this is the first report on the occurrence of oospores in tomato seeds. Whether such tomato seeds produce blighted seedlings remains to be shown.

Additional keywords: airborne oospores, epidemiology, potato, seedborne oospores, sexual recombination, sporulation.
Late blight caused by Phytophthora infestans (Mont.) De Bary is a devastating disease of potato and tomato worldwide (1). Increased aggressiveness of the fungus to tomato was recognized in various parts of the world $(12,21,23,29)$. In Israel, late blight severity in tomato crops increased significantly in the past several years, causing heavy yield losses especially in protected crops in plastic houses and net houses. In addition, fruit blight occurs more frequently in such crops. Blight causes economic losses to tomato seed growers, because seeds from blighted crops are either discarded or assigned to lower quality grades.

The reason for the increased aggressiveness of Phytophthora infestans to tomato is not clear. Legard et al. (23) showed that the fungal isolates originating from potato were less aggressive to tomato compared with those taken from tomato, which were equally aggressive to tomato and potato. They suggested that aggressiveness to tomato may be a recently acquired trait. Recent studies with Swiss and French isolates showed that A2 isolates are more frequent in tomato than in potato $(13,21)$ and that tomato isolates are much more aggressive to potato than potato isolates on tomato (22). Other studies (17) show equal aggressiveness to both potato and tomato of either isolates. A major reason that may have affected the behavior of the fungus in tomato is the recent displacement of the old fungal population by new isolates that migrated from Mexico $(10,11,14)$. The immigrant genotypes, composed of both A1 and A2, often showed some degree of host specialization to potato or tomato $(5,20,23)$. Fungal populations in France were largely separated on potato and tomato despite the occurrence of limited gene flow between the populations (21). Genetic diversity among tomato isolates was higher than among potato isolates (20), suggesting that sexual recombination was more frequent in tomato than in potato. The US-11 sexual recombinant possesses high fitness to tomato, causing severe epidemics on greenhouse and field-grown tomato in the United States (12).

The role of tomato in facilitating the establishment of sexually fit recombinant genotypes is not clear. It may result from the abil-

Corresponding author: Y. Cohen; E-mail address: coheny@mail.biu.ac.il

Publication no. P-2001-0904-02R

(c) 2001 The American Phytopathological Society ity of tomato foliage to produce more oospores than potato foliage (3) and especially due to the abundant production of oospores in tomato fruits in nature $(29,30)$ relative to potato tubers $(24,27)$. Mayton et al. (25) reported that oospores from tomato fruits were infectious to tomato and potato leaflets, whereas oospores from potato tubers did not cause infection. It, thus, appears that tomato fruits may have a significant role in the evolution of recombinant genotypes of Phytophthora infestans because they may carry abundant infectious oospores. Infected fruits, often dumped by the farmer, may supply oosporic inoculum when infected by both A1 and A 2 fungal isolates. In addition, they may be transported to distant locations by commercial trade, thus, establishing new genotypes in remote areas.

The objectives of this study were to quantify the ability of Phytophthora infestans to produce oospores in tomato fruits, to study some biotic and abiotic factors that affect oospore production in tomato fruits, and because $(31,32)$ Phytophthora infestans is seedborne, to observe whether oospores can be produced in tomato seeds. Surprisingly, the study showed that oospores may become both airborne and seedborne.

\section{MATERIALS AND METHODS}

Seeds, plants, and fruits. Tomato seeds of cv. ZH were taken from our own collection. Seeds of cvs. M-82, Gedera-146 (F1), Gedera-5108 (F1), and Gedera-8892 (F1) were provided by Zeraim Ltd., Gedera, Israel; cv. Brigade (F1) from Makhteshim Ltd., Beer-Sheba, Israel; cv. Hazera-144 (F1) from Hazera Genetics Ltd., Brorim, Israel; cvs. Pieralbo and Pierline (carrying the gene Ph-2 for resistance to Phytophthora infestans) from M. Pitrat, INRA, Montfavet, France; cvs. Agata, Allan, Belig-Naliv, Iskorka, Korsar, Sibir, Sinbad, Solnechnig, and Talalychin from Sortsemovoch Ltd., Moscow, Russia; cv. CLN-1314 from AVRDC, Shanhua, Taiwan; and cv. Xiaosheng-nu (F1) from Ho-Huan Ltd., Puli Nantou, Taiwan.

Plants were grown at Bar-Ilan University Farm in plastic net (50 mesh) houses $(45 \times 6 \mathrm{~m}) 3 \mathrm{~m}$ high. Irrigation and fertilizers were applied according to recommendations, with no pesticides applied. During the two periods of fruit harvest (spring 2000 and autumn 2000), no late blight occurred in the farm. 
Experiments were conducted with fruits at the mature green stage, unless stated otherwise. Such fruits reached their full size and mass and turn pink several days after harvest. Fruits were washed thoroughly with water and blotted dry and their stem-end with sepal leaves was removed (unless stated otherwise), placed on filter paper on a base or a lid of petri dishes, and inoculated with Phytophthora infestans.

Fungal isolates and fruit inoculation. Sixteen isolates of $P h y$ tophthora infestans, nine A1 and seven A2, were used for A1 + A2 coinoculation of tomato fruits. Their source (potato or tomato), country of origin, and sensitivity to metalaxyl are given in Table 1 .

Fungal sporangia of the various isolates were produced on potato tuber slices at $15^{\circ} \mathrm{C}$ in the dark. Sporangial suspensions $(2 \times$ $10^{3}$ per $\mathrm{ml}$ ) of $\mathrm{A} 1$ and $\mathrm{A} 2$ isolates in glass-distilled water were mixed at a 1:1 ratio and inoculated onto tomato fruits with one of the following methods: (i) injecting sporangial suspension $(0.1 \mathrm{ml}$ per site) into the stem scar or into the pericarp with a 1-ml syringe equipped with a needle $(0.6 \times 20 \mathrm{~mm})$; (ii) placing three $5-\mathrm{mm}$ diameter filter paper disks soaked in the sporangial suspension mixture either underneath the sepal leaves of a fruit, on the stem scar (calyx removed), or on the fruit skin; and (iii) a whole spray of $\approx 0.5 \mathrm{ml}$ of sporangial suspension per fruit with the aid of a fine glass atomizer.

Inoculated fruits were placed in moisture-saturated atmosphere at $15^{\circ} \mathrm{C}$ in the dark for 2 days, unless stated otherwise, and kept in growth cabinets at $15^{\circ} \mathrm{C}$ and 60 to $70 \%$ relative humidity (RH), and illuminated $12 \mathrm{~h} /$ day with fluorescent light of $\approx 100 \mu \mathrm{E} \mathrm{m}^{-2} \mathrm{~s}^{-1}$, unless stated otherwise. Oospores in detached leaflets of tomato and potato were produced, for comparison purposes, according to the method described previously (3).

Oospores in naturally infected tomato fruits. Severe epidemics of late blight occurred in tomato crops in southwestern Israel

TABLE 1. A1 and A2 isolates of Phytophthora infestans used for oospore formation in tomato fruits

\begin{tabular}{|c|c|c|c|c|}
\hline Isolate & Source $^{\mathrm{x}}$ & Origin $^{y}$ & Mating type & $\begin{array}{l}\text { Metalaxyl } \\
\text { sensitivity }^{z}\end{array}$ \\
\hline BI & $\mathrm{T}$ & IL & A1 & $\mathrm{S}$ \\
\hline Drucker & $\mathrm{P}$ & IL & $\mathrm{A} 1$ & $\mathrm{~S}$ \\
\hline HA & $\mathrm{T}$ & IL & A1 & $\mathrm{R}$ \\
\hline EHB & $\mathrm{T}$ & IL & $\mathrm{A} 1$ & $\mathrm{~S}$ \\
\hline GR & $\mathrm{T}$ & IL & A 1 & $\mathrm{~S}$ \\
\hline TAL & $\mathrm{T}$ & IL & A1 & $\mathrm{S}$ \\
\hline TO497 & $\mathrm{T}$ & $\mathrm{CH}$ & A1 & $\mathrm{S}$ \\
\hline 314 & $\mathrm{P}$ & $\mathrm{J}$ & A1 & $\mathrm{S}$ \\
\hline US-1 & $\mathrm{P}$ & US & A1 & $\mathrm{S}$ \\
\hline 317 & $\mathrm{P}$ & $\mathrm{J}$ & A2 & $\mathrm{R}$ \\
\hline NT & $\mathrm{T}$ & IL & A2 & $\mathrm{S}$ \\
\hline KG & $\mathrm{T}$ & IL & A2 & $\mathrm{S}$ \\
\hline YA & $\mathrm{T}$ & IL & $\mathrm{A} 2$ & $\mathrm{~S}$ \\
\hline 367 & $\mathrm{P}$ & IL & A2 & $\mathrm{R}$ \\
\hline TUR & $\mathrm{T}$ & $\mathrm{T}$ & $\mathrm{A} 2$ & $\mathrm{~S}$ \\
\hline US-7 & $\mathrm{P}$ & US & $\mathrm{A} 2$ & $\mathrm{R}$ \\
\hline US-8 & $\mathrm{P}$ & US & $\mathrm{A} 2$ & $\mathrm{R}$ \\
\hline
\end{tabular}

${ }^{\mathrm{x}} \mathrm{P}=$ potato; and $\mathrm{T}=$ tomato

y $\mathrm{CH}=$ Switzerland, IL = Israel, $\mathrm{J}=$ Japan, $\mathrm{T}=$ Turkey, and US = United States.

${ }^{z} \mathrm{~S}=$ sensitive; and $\mathrm{R}=$ resistant. during 1998 to 2000, especially in plastic house and net housegrown crops. Blighted tomato fruits were collected from 20 such houses during that period and examined microscopically for the presence of oospores. Some fruits from each house were placed in a moisture-saturated atmosphere to allow for fungal sporulation. Sporangia produced were tested for mating type, virulence factors, and sensitivity to metalaxyl according to the methods described elsewhere $(3,13,18)$.

Microscopical observations of oospores in fruits and seeds. Blighted fruits were taken for microscopical analysis of oospore formation in the various parts of the fruit and in the seeds. Fungal structures developed on the stem scar were also examined when fruits were constantly kept in a moisture-saturated atmosphere. Each fruit was cut along the stem scar in two halves, and three pieces of tissue $(\approx 5 \times 5 \mathrm{~mm})$ were removed, with the aid of a scalpel, from the pericarp, main vascular tissues below the stem scar, columella, and the seed cavity (placenta) (16). Tissue pieces were placed in $50 \%$ glycerol in water on glass slides, covered with coverslip, pressed gently, and examined. The number of oospores per microscope field $\left(1.56 \mathrm{~mm}^{2}\right)$ at $\times 160$ magnification was counted in each piece, and the mean number of oospores for the three pieces was calculated. Seeds were removed from the infected fruits, and 20 seeds per fruit were gently incised with the aid of a narrow scalpel so that the embryo was separated from the seed coat (9). Seed parts were placed in 50\% glycerol on a glass slide, covered with a coverslip, pressed gently, and examined for the presence of oospores.

\section{RESULTS}

Oospores in naturally blighted tomato fruits. Fruit blight in nature most often started from infection of the sepal leaves or from the contact zone between fruits in a bunch. Both sites may hold free water, required for infection, for longer periods than the free fruit surface. Blighted fruits always remained attached to the plant. Under moist conditions and in the absence of fungicides, fungal sporulation appeared on the fruit surface. Interestingly, some of our breeding lines, when tested under natural epiphytotics in the southwestern part of Israel, were heavily infected in their fruits while being free of symptoms on the foliage, indicating differential expression of resistance in leaves versus fruits. One hundred fully blighted fruits collected from 20 commercial plastic or net houses during 1998 to 2000 failed to show oospores. Mating-type determination of sporangia from such fruits revealed the presence of the A1 mating type only. Isolates were all sensitive to metalaxyl and all were complex races carrying 7 to 8 virulence factors. The absence of oospores in these fruits was attributed to the absence of the A2 mating type. Isolates collected from neighboring potato crops were also of the A 1 mating type, sensitive to metalaxyl, and carried similar 7 to 8 virulence factors. Isolates recovered from tomato fruits or potato leaves were fully compatible on either potato or tomato leaves.

Method of fruit inoculation and blight development. Fruits at the mature green stage showed necrotic blight symptoms when inoculated by either method. However, sporangial injection into the fruit was often associated with soft bacterial contaminations, but much less so if done into the stem scar. Fruit inoculations,

TABLE 2. Progress of blight necrosis and occurrence of oospores of Phytophthora infestans in tomato fruits inoculated at various sites of the fruit

\begin{tabular}{|c|c|c|c|c|c|c|c|}
\hline \multirow[b]{2}{*}{ Site of inoculation } & \multicolumn{2}{|c|}{$\%$ Fruit necrotic area } & \multicolumn{5}{|c|}{ Oospores in ${ }^{z}$} \\
\hline & External & Internal & Main vascular & Dorsal pericarp & Lateral pericarp & Ventral pericarp & Columella \\
\hline Stem scar & 40 & 40 & $270 \pm 85$ & $155 \pm 111$ & 0 & 0 & $124 \pm 87$ \\
\hline Blossom end & 40 & 40 & 0 & 0 & 0 & $84 \pm 84$ & $50 \pm 64$ \\
\hline Lateral skin & 40 & 10 & 0 & 0 & $125 \pm 104$ & 0 & 0 \\
\hline
\end{tabular}

y In 6-cm diameter mature green fruits of cv. Agata.

${ }^{\mathrm{z}}$ Mean number of oospores $\pm \mathrm{SD}$ per $1.56 \mathrm{~mm}^{2}$ of tissue, taken from six fruits per treatment, at 16 days postinoculation $\left(15^{\circ} \mathrm{C}, 60\right.$ to $\left.70 \% \mathrm{RH}\right)$. 
therefore, were mostly done by either scar injection or attaching filter paper disks holding sporangia to the stem scar or to the skin of the fruit. Normally with these methods, initial blight symptoms were seen at 5 to 7 days postinoculation (dpi) at $15^{\circ} \mathrm{C}$.

Fruit maturity and fruit size affect blight development. Red, fully mature fruits developed much reduced blight symptoms compared with immature or mature green fruits. For instance, the percentages of blighted fruit in plum cherry cv. Xiaosheng-nu at 8 , 10 , and 12 days after a spray inoculation were, respectively, 30, 40 , and $60 \%$ for mature green fruit versus 0,5 , and $5 \%$ for mature red fruit. In mature green fruits of other cultivars, the time required for the blight to cover the whole fruit surface was dependent on fruit size and cultivar. In most cultivars, small fruits (3 to $4 \mathrm{~cm}$ in diameter) were fully blighted in approximately 8 to $10 \mathrm{dpi}$, whereas large fruits ( 7 to $8 \mathrm{~cm}$ in diameter) showed a full coverage at 15 to 20 dpi. Some cultivars showed 30 to $50 \%$ coverage at $20 \mathrm{dpi}$, probably due to genetic resistance. In commercial crops, under heavy epiphytotics, red fruits showed a much reduced incidence of blight compared with green fruits (various stages). In the breeding line $\mathrm{ZH}$, which carries the rin (ripening inhibitor) (15) gene, fruits turn yellow when fully ripen. In this line, mature yellow fruits as well as mature green fruits of the same size (7-cm diameter) became fully blighted by Phytophthora infestans in approximately $15 \mathrm{dpi}$.

Oospore production in fruits. Site of inoculation affects oospore formation. Fruits (6-cm diameter) of cv. Agata at the mature green stage were inoculated by the filter paper disk method with GR (A1) + YA (A2) sporangia on either the stem scar, the blossom end, or the lateral skin. At $16 \mathrm{dpi}\left(15^{\circ} \mathrm{C}, 12 \mathrm{~h} \mathrm{light/day,}\right.$ and 60 to $70 \% \mathrm{RH}$ ), blight symptom covered $\approx 40 \%$ of the fruit surface around the site of inoculation. Internal necrosis covered an area of approximately 40,40 , and $10 \%$ of the cut fruit surface in fruits inoculated on the stem scar, blossom end, and the lateral skin, respectively (Table 2). Inoculation onto the stem scar allowed for oospores to develop in the main vascular tissues below the scar, in the dorsal pericarp, and the columella. The lateral pericarp was necrotic but with no oospores, probably because of the short period lapsed between onset of necrosis and sampling. The ventral pericarp was not infected (Table 2). Blossom end inoculation resulted with oospore formation in the ventral pericarp and the columella, whereas lateral skin infection resulted with oospore formation in only the lateral pericarp (Table 2).

TABLE 3. Oospore formation by 25 combinations of A1 + A2 isolates of Phytophthora infestans from potato $(\mathrm{P})$ or tomato $(\mathrm{T})$ origin in tomato fruits and tomato leaves ${ }^{\mathrm{y}}$

\begin{tabular}{lcccccc}
\hline & \multicolumn{5}{c}{ A2 isolate } \\
\cline { 2 - 6 } A1 isolate & $317(\mathrm{P})$ & US-8 (P) & NT (T) & KG (T) & TUR (T) & Mean \\
\hline Fruits (M-82) & & & & & & \\
$314(\mathrm{P})$ & $23 \mathrm{ab}$ & $18 \mathrm{a}$ & $0 \mathrm{a}$ & $62 \mathrm{~b}$ & $94 \mathrm{~b}$ & $39 \mathrm{~A}$ \\
US-1 (P) & $0 \mathrm{a}$ & $13 \mathrm{a}$ & $56 \mathrm{~b}$ & $3 \mathrm{a}$ & $15 \mathrm{a}$ & $17 \mathrm{~A}$ \\
Drucker (P) & $43 \mathrm{ab}$ & $51 \mathrm{~b}$ & $0.3 \mathrm{a}$ & $39 \mathrm{ab}$ & $65 \mathrm{~b}$ & $40 \mathrm{~A}$ \\
TO497 (T) & $37 \mathrm{ab}$ & $2 \mathrm{a}$ & $0 \mathrm{a}$ & $75 \mathrm{ab}$ & $117 \mathrm{~b}$ & $46 \mathrm{~A}$ \\
BI (T) & $50 \mathrm{bc}$ & $28 \mathrm{ab}$ & $0 \mathrm{a}$ & $70 \mathrm{c}$ & $39 \mathrm{~b}$ & $37 \mathrm{~A}$ \\
Mean & $30 \mathrm{ab}$ & $22 \mathrm{a}$ & $11 \mathrm{a}$ & $50 \mathrm{ab}$ & $66 \mathrm{~b}$ & $\ldots$ \\
Leaves (ZH) & & & & & & \\
314 & $60 \mathrm{~b}$ & $0 \mathrm{a}$ & $0 \mathrm{a}$ & $72 \mathrm{~b}$ & $50 \mathrm{~b}$ & $36 \mathrm{AB}$ \\
US-1 & $1 \mathrm{a}$ & $0.3 \mathrm{a}$ & $0 \mathrm{a}$ & $2 \mathrm{a}$ & $4 \mathrm{a}$ & $2 \mathrm{~A}$ \\
Drucker & $53 \mathrm{c}$ & $0 \mathrm{a}$ & $0 \mathrm{a}$ & $20 \mathrm{~b}$ & $57 \mathrm{c}$ & $26 \mathrm{AB}$ \\
TO497 & $37 \mathrm{a}$ & $34 \mathrm{a}$ & $53 \mathrm{~b}$ & $27 \mathrm{a}$ & $25 \mathrm{a}$ & $35 \mathrm{AB}$ \\
BI & $37 \mathrm{~b}$ & $0 \mathrm{a}$ & $0 \mathrm{a}$ & $73 \mathrm{c}$ & $127 \mathrm{~d}$ & $47 \mathrm{~B}$ \\
Mean & $37 \mathrm{ab}$ & $7 \mathrm{a}$ & $11 \mathrm{ab}$ & $39 \mathrm{ab}$ & $52 \mathrm{~b}$ & $\ldots$ \\
\hline
\end{tabular}

${ }^{y}$ Fruits were inoculated by injecting sporangia into the stem scar. Leaflets were drop-inoculated in petri dishes.

${ }^{\mathrm{z}}$ Values are the number of oospores per $1.56 \mathrm{~mm}^{2}$ of tissue taken at 12 days postinoculation $\left(15^{\circ} \mathrm{C}, 60\right.$ to $\left.70 \% \mathrm{RH}\right)$ from the main vascular tissue below the stem scar. Small letters following values in rows represent significant differences at 5\% probability level (analysis of variance). Capital letters similarly represent differences in columns.
Fruits versus leaves. Sporangia of either one of five A1 isolates were mixed with sporangia of either one of five A2 isolates at a 1:1 ratio and were inoculated onto either detached leaflets (3) or fruits of tomato. Oospore counts were recorded at $12 \mathrm{dpi}$. Table 3 shows that of the $25 \mathrm{~A} 1+\mathrm{A} 2$ mixed sporangial inocula, 21 and 18 were able to produce oospores in fruits and leaves, respectively. In fruits, three failures occurred with the NT isolate (A2 from tomato) and one with US-1, whereas in leaves, four and three failures occurred with NT and US-8 (A2 from potato), respectively. Oospore counts were dependent on the specific pairing of the isolates (Table 3). Nevertheless, in both fruits and leaves, the A2 tomato isolate TUR was the best partner for producing oospores, whereas US-1 (A1 from potato) was the poorest partner. Interestingly, US-1 and US-8 were better partners in fruits than in leaves. We observed (24) poor or no oospore formation with these isolates in potato tubers. In addition, Medina et al. (27) reported poor oospore formation in potato tubers with isolates belonging to the US- 1 and US- 8 genotypes. The data in Table 3 also indicate that the host of origin of the isolates (potato or tomato) had a small but significant effect on oospore production in tomato tissues. Grand means of oospore counts for $\mathrm{P}+\mathrm{P}, \mathrm{P}+\mathrm{T}$, and $\mathrm{T}+\mathrm{T}$ isolates were $25 \pm 19,35 \pm 29$, and $50 \pm 46$ in fruits, and $19 \pm 29,24 \pm 25$, and $50 \pm 45$ in leaves, respectively.

Effect of temperature. Oospore production in tomato fruits was dependent on temperature during colonization (Table 4). Mature green fruits of three cultivars were coinoculated with either one of two mixtures of $\mathrm{A} 1+\mathrm{A} 2$ sporangia and at 1 day after inoculation $\left(15^{\circ} \mathrm{C}\right)$ were incubated at either 12,17 , or $23^{\circ} \mathrm{C}$. At $11 \mathrm{dpi}$, a grand mean of 22, 21, and 9 oospores, and at $22 \mathrm{dpi}$, a grand mean of 168,158 , and 5 oospores per $1.56 \mathrm{~mm}^{2}$ of fruit tissue was counted at 12,17 , and $23^{\circ} \mathrm{C}$, respectively (Table 4$)$. No significant difference in oospore counts was obtained between 12 and $17^{\circ} \mathrm{C}$. At $22 \mathrm{dpi}$, incubation at $23^{\circ} \mathrm{C}$ significantly reduced oospore formation, although blight severity was similar to the that observed at $17^{\circ} \mathrm{C}$. The three cultivars were not equally supportive of oospore formation; in 5 of 12 situations, cv. Brigade supported significantly higher oospore yield than the other two cultivars (Table 4).

Effect of plant cultivar and fungal isolate. The ability of fruits of five cultivars to support oospore formation was further tested with five pairs of A1 + A2 fungal isolates, three pairs of potato origin and two pairs of tomato origin. All fruits were fully

TABLE 4. The effect of temperature on oospore formation by Phytophthora infestans in tomato fruits ${ }^{\mathrm{x}}$

\begin{tabular}{|c|c|c|c|c|c|c|}
\hline \multirow[b]{2}{*}{ Cultivar $^{\mathrm{y}}$} & \multicolumn{3}{|c|}{11 days postinoculation ${ }^{z}$} & \multicolumn{3}{|c|}{22 days postinoculation ${ }^{z}$} \\
\hline & $12^{\circ} \mathrm{C}$ & $17^{\circ} \mathrm{C}$ & $23^{\circ} \mathrm{C}$ & $12^{\circ} \mathrm{C}$ & $17^{\circ} \mathrm{C}$ & $23^{\circ} \mathrm{C}$ \\
\hline \multicolumn{7}{|l|}{$314+317$} \\
\hline $\mathrm{ZH}$ & $18 \mathrm{bA}$ & $21 \mathrm{bA}$ & $5 \mathrm{aA}$ & $123 \mathrm{bA}$ & $153 \mathrm{bB}$ & $3 \mathrm{aA}$ \\
\hline M-82 & $19 \mathrm{bA}$ & $18 \mathrm{bA}$ & $11 \mathrm{aB}$ & $110 \mathrm{bA}$ & $110 \mathrm{bA}$ & $4 \mathrm{aA}$ \\
\hline Brigade & $30 \mathrm{cB}$ & $24 \mathrm{bA}$ & $14 \mathrm{aB}$ & $175 \mathrm{bA}$ & $175 \mathrm{bC}$ & $8 \mathrm{aB}$ \\
\hline Mean & $22 \mathrm{a}$ & $21 \mathrm{a}$ & $10 \mathrm{a}$ & $136 \mathrm{~b}$ & $146 \mathrm{~b}$ & $5 \mathrm{a}$ \\
\hline \multicolumn{7}{|l|}{$\mathrm{BI}+\mathrm{KG}$} \\
\hline $\mathrm{ZH}$ & $15 \mathrm{bA}$ & $24 \mathrm{cA}$ & $4 \mathrm{aA}$ & $203 \mathrm{bBC}$ & $188 \mathrm{bB}$ & $5 \mathrm{aAB}$ \\
\hline M-82 & $16 \mathrm{bA}$ & $17 \mathrm{bA}$ & $7 \mathrm{aA}$ & $168 \mathrm{cB}$ & $128 \mathrm{bA}$ & $4 \mathrm{aA}$ \\
\hline Brigade & $35 \mathrm{cB}$ & $24 \mathrm{bA}$ & $15 \mathrm{aB}$ & $230 \mathrm{cC}$ & $198 \mathrm{bB}$ & $8 \mathrm{aB}$ \\
\hline Mean & $22 \mathrm{a}$ & $22 \mathrm{a}$ & $9 \mathrm{a}$ & $200 \mathrm{c}$ & $155 \mathrm{~b}$ & $6 \mathrm{a}$ \\
\hline Grand mean & $22 \mathrm{a}$ & $21 \mathrm{a}$ & $9 a$ & $168 \mathrm{~b}$ & $158 \mathrm{~b}$ & $5 \mathrm{a}$ \\
\hline
\end{tabular}

$\mathrm{x}$ Fruits were inoculated by injecting sporangia into the stem scar.

y Pair $314+317$ produced $95 \pm 12$ and $58 \pm 18$ oospores per $1.56 \mathrm{~mm}^{2}$ in detached leaves of tomato $(\mathrm{ZH})$ and potato (Alpha), respectively, and pair $\mathrm{BI}+\mathrm{KG}-115 \pm 15$ and $70 \pm 20$ oospores per $1.56 \mathrm{~mm}^{2}$, respectively, at $17^{\circ} \mathrm{C}$.

${ }^{\mathrm{z}}$ Values represent the number of oospores per $1.56 \mathrm{~mm}^{2}$ of vascular tissue taken from the pericarp a few millimeters below the stem scar. Small letters following values in rows represent significant differences at $5 \%$ probability level $(n=4)$, separately for each one of the four panels of the table. Capital letters similarly represent differences in columns (analysis of variance). 
blighted at $21 \mathrm{dpi}$. Out of the 25 cultivars $\times$ isolates inoculations, only one did not show oospores inside the fruits at $21 \mathrm{dpi}$ (Table 5). However, oospore density varied greatly, ranging from 9 to 250 oospores per $1.56 \mathrm{~mm}^{2}$ of tissue, due to an obvious interaction between isolate pairs and host cultivars. Highest oospore counts were obtained in fruits inoculated with the two isolate pairs originated from tomato, but these counts were not significantly different from counts obtained for fruits inoculated with two isolate pairs originated from potato (Table 5).

Sexual structures on fruit surface. Mature green fruits of four cultivars were inoculated onto the stem scar with five A1 + A2 sporangial mixtures. Inoculated fruits were kept in moist chambers in the dark at $15^{\circ} \mathrm{C}$. At $9 \mathrm{dpi}$, necrosis was visible on the fruits and aerial fungal structures developed on the stem scar (Fig. 1A). Microscopical examination revealed the presence of sporangia, oogonia, and a few oospores in the mycelium developing on the scar surface in most fruits (Table 6). The number of oogonia and oospores in mycelial mats removed from the stem scar ranged between 0 and 23 per $1.56 \mathrm{~mm}^{2}$. 'Hazera 144' allowed for the lowest production of oogonia and oospores on fruit surface. The number of oospores produced inside the fruit, ranging from 48 to 140 per $1.56 \mathrm{~mm}^{2}$ of tissue, was much larger compared with that on fruits surface. Again, cv. Hazera 144 allowed for the lowest production of oospores relative to the other three cultivars (Table $6)$. Isolate pairs did not differ significantly in their reproduction ability (Table 6).

The same A1 + A2 sporangial mixtures were used to inoculate other fruits with their calyx attached. Filter paper disks holding sporangial suspension were inserted between the sepal leaves and the fruit skin. Fruits were kept at $100 \% \mathrm{RH}$ at $15^{\circ} \mathrm{C}$ for $15 \mathrm{dpi}$. Fungal structures that developed on the fruit skin around the calyx were found to carry oospores, thus, reaffirming the possibility that oospores may be released from fruit surface to become airborne. Fruits of cvs. ZH, Hazera 144, Gedera 5108, and M-82 carried in the aerial mycelium a mean of $19 \pm 3,1 \pm 2,13 \pm 5$, and $8 \pm$ 7 oospores per $1.56 \mathrm{~mm}^{2}$, respectively, compared with $112 \pm 17$, $60 \pm 14,103 \pm 10$, and $87 \pm 17$ oospores per $1.56 \mathrm{~mm}^{2}$ in the dorsal pericarp.

Distribution of oospores inside the fruit. No oospores were detected in mature green fruits of 13 tomato cultivars inoculated on the stem scar with sporangia of either HA (A1) or TUR (A2) (data not shown). Both isolates were similarly aggressive to the various cultivars (data not shown). Data on oospore production in fruits coinoculated with the mixed HA (A1) + TUR (A2) isolates are presented in Table 7 . The extent of fruit necrosis varied with the cultivar (Table 7). Oospores were formed in relatively large numbers in the vascular tissues below the stem scar (Fig. 1B) and to a lesser extent in the dorsal pericarp tissue (Table 7). The lateral and ventral pericarp tissues were less supportive of oospore formation, especially so in cultivars that showed partial fruit necrosis. The placental gel-like tissue around the seed enabled oospore formation in large numbers in only cvs. Allan and Korsar (Table 7; Fig. 1C). In seeds of these cultivars, oospores were also found enclosed between the seed hairs (Table 7; Fig. 1D) and encrusted in the inner surface of the seed coat (Fig. 1E and F). Fungal mycelium was often seen growing on the endosperm (Fig. 1G). In one seed of cv. Allan and in two seeds of cv. Korsar, a single oospore was detected in the embryo (Fig. 1H).

\section{DISCUSSION}

The increasing volume of data indicates the significant role of oospores of Phytophthora infestans in the epidemiology of late blight in potato and tomato $(7,25,26,30)$. Emphasis was given to oospores as soilborne inoculum $(1,25,30)$ with the premise that these structures are mainly formed in leaves and stems (3). When blighted foliage-carrying oospores defoliate and incorporate in the soil, oospores released after decomposition may infect the subsequent crop. Recent studies $(25,30)$ showed that oospores buried in soil in the field survived for 18 to 48 months and could cause infection in leaves of potato and tomato. Another report (12) suggested an important role of tomato in supporting the establishment of recombinant isolates in the fungal population, although that role was not exactly elucidated.

Our previous study revealed that oospores were produced (up to 100 per $\mathrm{mm}^{2}$ ) in leaves of tomato or potato when floated on water (3). Much reduced oospore yields were obtained in leaves of intact plants even under high humidity conditions (3). In the field in Israel, oospores were produced in only small numbers in leaves and stems, especially under heavy "rain" (sprinkling irrigation) (2). In the Netherlands, oospores were readily detected in blightaffected tomato leaflets and fruits and in leaflets of field crops and volunteer potato plants (30). Interestingly, potato tubers seldom supported oospore production (24). The reason for the failure of Phytophthora infestans to produce oospore in blighted tubers is yet obscure. The importance of monitoring oospores production in tubers relates to the large world trade of potato tubers and the danger of "trading" oospores with it.

The purpose of the present study was to investigate the potential role of tomato fruits and seeds as sources of sexual inoculum of Phytophthora infestans. To verify such a role, we studied some of the biotic and abiotic conditions under which oospores can be formed in the fruit and seed. The results of this study provided data concerning the potential significance of sexual reproduction of Phytophthora infestans in tomato fruits and seeds. We showed that oospores are readily formed in tomato fruits after coinoculation with A1 + A2 sporangia. Their density may reach as many as 160 oospores per $\mathrm{mm}^{2}$ of tissue, similar to or even higher than the number in leaves of potato or tomato floating on water (3) and much higher than in potato leaves in the field (2) or tomato leaves in net houses (Y. Cohen, unpublished data). Abundant oospores were formed at 12 to $17^{\circ} \mathrm{C}$ and a few at $23^{\circ} \mathrm{C}$, implicating their

TABLE 5. Production of oospores by Phytophthora infestans in tomato fruits of various cultivars ${ }^{\mathrm{x}}$

\begin{tabular}{|c|c|c|c|c|c|c|}
\hline \multirow[b]{3}{*}{ Tomato cultivar ${ }^{\mathrm{y}}$} & \multicolumn{6}{|c|}{$\mathrm{A} 1+\mathrm{A} 2$ isolates $^{\mathrm{z}}$} \\
\hline & Drucker + US-7 & $314+\mathrm{US}-7$ & $314+317$ & $\mathrm{BI}+\mathrm{KG}$ & $\mathrm{TO} 4+\mathrm{KG}$ & \\
\hline & $\mathrm{P}+\mathrm{P}$ & $\mathrm{P}+\mathrm{P}$ & $\mathrm{P}+\mathrm{P}$ & $\mathrm{T}+\mathrm{T}$ & $\mathrm{T}+\mathrm{T}$ & Mean \\
\hline $\mathrm{ZH}$ & $61 \mathrm{aBC}$ & $110 \mathrm{bcC}$ & $82 \mathrm{abA}$ & $121 \mathrm{cA}$ & $134 \mathrm{cB}$ & $102 \mathrm{~A}$ \\
\hline Brigade & $70 \mathrm{abCD}$ & $117 \mathrm{abC}$ & $165 \mathrm{bB}$ & $132 \mathrm{abA}$ & $130 \mathrm{abB}$ & $123 \mathrm{~A}$ \\
\hline Gedera 5108 & $107 \mathrm{bcD}$ & $80 \mathrm{bBC}$ & $150 \mathrm{cB}$ & $122 \mathrm{bcA}$ & $15 \mathrm{aA}$ & $95 \mathrm{~A}$ \\
\hline Gedera 146 & $23 \mathrm{aAB}$ & $62 \mathrm{abB}$ & $73 \mathrm{bA}$ & $212 \mathrm{cB}$ & $250 \mathrm{cC}$ & $124 \mathrm{~A}$ \\
\hline Hazera 8892 & $0 \mathrm{aA}$ & $9 \mathrm{aA}$ & $68 \mathrm{bA}$ & $123 \mathrm{cA}$ & $118 \mathrm{cB}$ & $64 \mathrm{~A}$ \\
\hline Mean & $52 \mathrm{a}$ & $75 \mathrm{ab}$ & $108 \mathrm{ab}$ & $142 \mathrm{~b}$ & $129 \mathrm{~b}$ & $\ldots$ \\
\hline
\end{tabular}

${ }^{x}$ Fruits were inoculated by injecting sporangia into the stem scar.

y In cvs. ZH, Brigade, and Gedera 5108, oospores were also produced in the aerial mycelium produced on the stem scar.

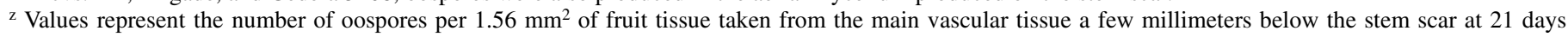
postinoculation $\left(15^{\circ} \mathrm{C}\right)$. Small letters following the values in rows indicate significant difference at $5 \%$ probability level. Capital letters show significant differences in columns $(n=6)$ (analysis of variance). $\mathrm{P}=$ potato origin; and $\mathrm{T}=$ tomato origin. 

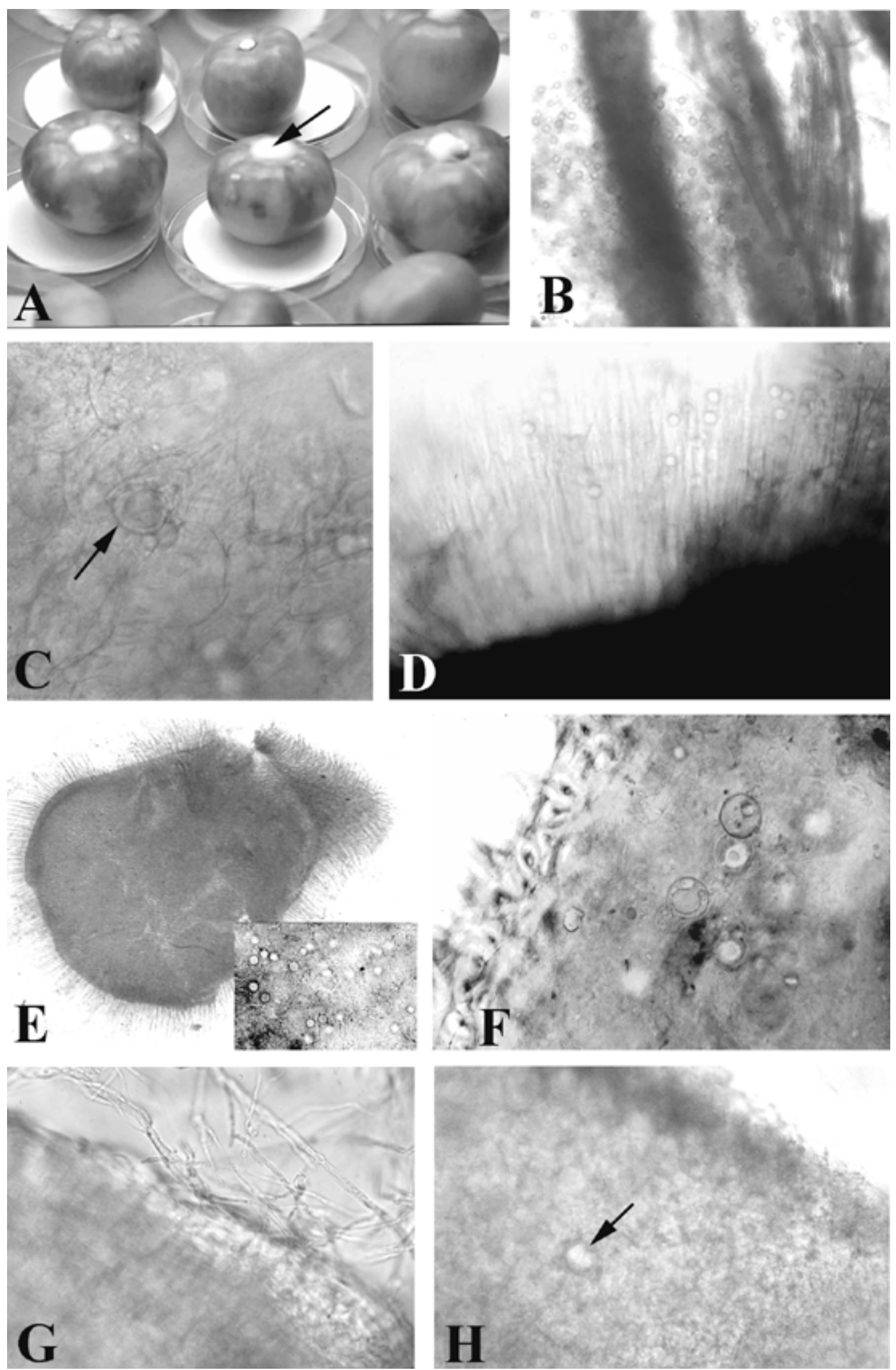

Fig. 1. A, Tomato fruits (cv. ZH) infected by Phytophthora infestans. Note aerial mycelium on the stem scar (arrow). Often oospores are formed by this mycelium $(\times 0.3)$. B, Oospores of Phytophthora infestans in the main vascular tissue of a tomato fruit. Tissue was taken a few millimeters below the stem scar. Note the xylem vessels (about $20 \mu \mathrm{m}$ in diameter). Oospores (about $30 \mu \mathrm{m}$ in diameter) were never observed inside vessels $(\times 40)$. C, An oospore of Phytophthora infestans in a placental cell (arrow) of a tomato fruit $(\times 335)$. D, Oospores of Phytophthora infestans enclosed between tomato seed hairs $(\times 78)$. E, The inner surface of a tomato seed coat encrusted with abundant oospores $(\times 14)$. Insert indicates a higher magnification of a portion of the inner surface of the seed coat with oospores of Phytophthora infestans $(\times 50)$. F, Oospores and oogonia of Phytophthora infestans on the inner surface of a tomato seed coat. Epidermal cell layer is on the left. Seed hairs are out of focus $(\times 233)$. G, Mycelia of Phytophthora infestans growing on the embryo surface of a tomato seed $(\times 400)$. Photo was taken after removing the seed coat $(\times 310)$. H, An oospore of Phytophthora infestans inside the embryo of a tomato seed. Photo was taken after removing the seed coat $(\times 155)$. 
possible formation in nature. Green fruits allowed for a faster blight development and consequently oospore formation than mature red fruits. The reasons for this differential susceptibility warrant further investigation.

Isolates of Phytophthora infestans originating from tomato were more fertile than those originating from potato. Interestingly, US-1 and US-8, which were poor partners in combination with other isolates for oospore production in leaves, were better producers of oospores in fruits, thus shedding some light on the role of tomato fruits in enhancing the establishment of recombinant genotypes in nature (12).

When inoculated fruits were kept in a moisture-saturated atmosphere, oospores formed on the fruit surface. Such a phenomenon was never observed with leaves of tomato or potato, in which oospores were only seen in the mesophyll $(2,3)$. This finding suggests that in tomato crops oospores may discharge from fruit surface to become airborne, and thus may cause, during the season, infection with recombinant genotypes as suspected by Miller and Johnson (28).

Fruits of all 20 cultivars and F1 hybrids tested were susceptible to the blight and allowed for oospore formation. We were surprised to learn (data not shown) that although some of our breeding lines were resistant in both their foliage and fruit against the blight, other lines were either susceptible in the foliage but resis- tant in the fruit or resistant in the foliage and susceptible in the fruit, suggesting a differential genetic control of resistance to Phytophthora infestans in leaves versus fruits. We reported on a similar phenomenon in potato foliage and tubers (19).

Oospores were formed in all parts of the fruit and in some cultivars reached the seed surface, anchoring between the seed hairs. Most importantly, in a few seeds, oospores developed inside the seed, on the inner surface of the seed coat and the embryo. Seed infection with Phytophthora infestans was reported in tomato by Vartanian and Endo in 1985 in California (31,32). At that time, inoculations were done with an A2 isolate and only mycelia of the pathogen were observed beneath the seed coat (32). We know of no other report on the occurrence of oospores of Phytophthora infestans in tomato seed. Some downy mildew pathogens have been reported to produce oospores in the seed of their host plants, e.g., Plasmopara halstedii in sunflower (4), Peronospora viciae in pea (6), and Peronospora manshurica in soybean (8).

The practical significance of our findings is twofold. First, tomato fruits may carry oospores and may be transported (within a country, between countries, and even between continents) to cause the establishment of new recombinant forms of the pathogen. Also, infected tomato fruits carrying oospores may serve as an inoculum source when dumped and discomposed. Second, tomato seed may carry oospores. It is not clear whether the commercial procedures

TABLE 6. Oogonia and oospore formation by Phytophthora infestans on the surface and inside tomato fruits ${ }^{\mathrm{x}}$

\begin{tabular}{|c|c|c|c|c|c|}
\hline \multirow[b]{2}{*}{$\mathrm{A} 1+\mathrm{A} 2$ isolates } & \multicolumn{5}{|c|}{ Tomato cultivar } \\
\hline & $\mathrm{ZH}$ & Hazera 144 & Gedera 5108 & M-82 & Mean \\
\hline \multicolumn{6}{|c|}{ Oogonia and oospores on fruit surface ${ }^{y}$} \\
\hline $314+317$ & $16 \mathrm{~b}$ & $0 \mathrm{a}$ & $8 a b$ & $12 \mathrm{~b}$ & $9 \mathrm{~A}$ \\
\hline $\mathrm{BI}+\mathrm{KG}$ & $23 \mathrm{~b}$ & $0 \mathrm{a}$ & $17 \mathrm{~b}$ & $18 \mathrm{~b}$ & $15 \mathrm{~A}$ \\
\hline $\mathrm{EHB}+\mathrm{YA}$ & $16 \mathrm{~b}$ & $0 \mathrm{a}$ & $11 \mathrm{~b}$ & $0 \mathrm{a}$ & $7 \mathrm{~A}$ \\
\hline $\mathrm{GR}+367$ & $19 \mathrm{ab}$ & $4 \mathrm{a}$ & $9 \mathrm{a}$ & $5 \mathrm{a}$ & $9 \mathrm{~A}$ \\
\hline $\mathrm{TAL}+\mathrm{TUR}$ & $19 \mathrm{~b}$ & $3 \mathrm{a}$ & $20 \mathrm{~b}$ & $4 \mathrm{a}$ & $12 \mathrm{~A}$ \\
\hline Mean & $19 \mathrm{c}$ & $1 \mathrm{a}$ & $13 \mathrm{bc}$ & $8 \mathrm{~b}$ & $\ldots$ \\
\hline \multicolumn{6}{|c|}{ Oospores in main vascular tissue $\mathrm{e}^{\mathrm{z}}$} \\
\hline $314+317$ & $98 \mathrm{~b}$ & $48 \mathrm{a}$ & $90 \mathrm{~b}$ & $78 \mathrm{ab}$ & $86 \mathrm{~A}$ \\
\hline $\mathrm{BI}+\mathrm{KG}$ & $110 \mathrm{a}$ & $83 \mathrm{a}$ & $100 \mathrm{a}$ & $105 \mathrm{a}$ & $100 \mathrm{~A}$ \\
\hline $\mathrm{EHB}+\mathrm{YA}$ & $98 \mathrm{~b}$ & $55 \mathrm{a}$ & $100 \mathrm{~b}$ & $98 \mathrm{~b}$ & $88 \mathrm{~A}$ \\
\hline $\mathrm{GR}+367$ & $115 \mathrm{~b}$ & $68 \mathrm{a}$ & $108 \mathrm{ab}$ & $63 \mathrm{a}$ & $88 \mathrm{~A}$ \\
\hline TAL + TUR & $140 \mathrm{~b}$ & $50 \mathrm{a}$ & $118 \mathrm{~b}$ & $90 \mathrm{ab}$ & $99 \mathrm{~A}$ \\
\hline Mean & $112 \mathrm{c}$ & $60 \mathrm{a}$ & $103 \mathrm{bc}$ & $87 \mathrm{~b}$ & $\ldots$ \\
\hline
\end{tabular}

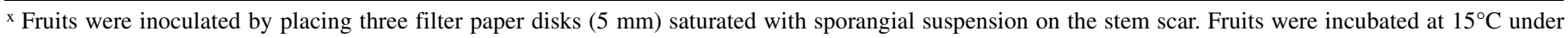
moisture-saturated atmosphere for 9 days postinoculation. Small letters following figures in rows represent differences at $5 \%$ probability level $(n=4)$. Capital letters similarly represent differences in columns (analysis of variance).

y Values represent the number of oogonia and oospores per $1.56 \mathrm{~mm}^{2}$ of mycelial mat removed from the surface of the fruit around stem scar.

${ }^{\mathrm{z}}$ Values represent the number of oospores per $1.56 \mathrm{~mm}^{2}$ of tissue taken from the vascular tissue a few millimeters below the stem scar.

TABLE 7. Distribution of oospores of Phytophthora infestans in various parts of tomato fruits of various cultivars ${ }^{\mathrm{x}}$

\begin{tabular}{|c|c|c|c|c|c|c|c|c|c|c|}
\hline \multirow[b]{3}{*}{ Cultivar } & \multirow{2}{*}{\multicolumn{2}{|c|}{$\%$ Fruit necrosis $^{\mathrm{y}}$}} & \multicolumn{6}{|c|}{ Oospores per $1.56 \mathrm{~mm}^{2}$ of tissue ${ }^{\mathrm{z}}$} & \multicolumn{2}{|c|}{ No. of seeds with oospores } \\
\hline & & & \multirow{2}{*}{$\begin{array}{c}\text { Main } \\
\text { vascular }\end{array}$} & \multirow{2}{*}{$\begin{array}{c}\text { Dorsal } \\
\text { pericarp }\end{array}$} & \multirow{2}{*}{$\begin{array}{c}\text { Lateral } \\
\text { pericarp }\end{array}$} & \multirow{2}{*}{$\begin{array}{c}\text { Ventral } \\
\text { pericarp }\end{array}$} & \multirow[b]{2}{*}{ Columella } & \multirow[b]{2}{*}{ Placenta } & \multirow{2}{*}{$\begin{array}{c}\text { Between } \\
\text { seed hairs }\end{array}$} & \multirow[b]{2}{*}{ Inside seed } \\
\hline & External & Internal & & & & & & & & \\
\hline Solnechnig & 30 & 30 & $29 \pm 8$ & $48 \pm 4$ & 0 & 0 & 0 & 0 & 0 & 0 \\
\hline Sibir & 40 & 20 & 0 & $9 \pm 6$ & 0 & 0 & 0 & 0 & 0 & 0 \\
\hline Belig Naliv & 50 & 30 & $25 \pm 14$ & $33 \pm 10$ & 0 & 0 & 0 & 0 & 0 & 0 \\
\hline Iskorka & 50 & 50 & $53 \pm 9$ & 0 & 0 & 0 & $53 \pm 8$ & 0 & 0 & 0 \\
\hline Olga & 60 & 100 & $93 \pm 4$ & $65 \pm 7$ & 0 & $9 \pm 10$ & 0 & 0 & 0 & 0 \\
\hline Talalychin & 80 & 50 & $102 \pm 11$ & $11 \pm 2$ & 0 & 0 & $85 \pm 11$ & 0 & 0 & 0 \\
\hline Agata & 90 & 100 & $130 \pm 10$ & $18 \pm 4$ & 0 & 0 & $38 \pm 8$ & 0 & 0 & 0 \\
\hline Allan & 90 & 100 & $67 \pm 8$ & $9 \pm 4$ & $7 \pm 3$ & 0 & $2 \pm 1$ & $24 \pm 28$ & 3 & 1 \\
\hline Sindbad & 100 & 80 & $25 \pm 9$ & $20 \pm 8$ & 0 & 0 & 0 & 0 & 0 & 0 \\
\hline Korsar & 100 & 100 & $85 \pm 11$ & $80 \pm 7$ & $1 \pm 0.7$ & 0 & $78 \pm 11$ & $65 \pm 11$ & 7 & 2 \\
\hline Pierline & 100 & 100 & $138 \pm 23$ & $78 \pm 34$ & $45 \pm 19$ & $8 \pm 4$ & $111 \pm 19$ & $2 \pm 2$ & 0 & 0 \\
\hline Pieralbo & 100 & 100 & $33 \pm 11$ & $20 \pm 9$ & $10 \pm 4$ & $17 \pm 5$ & $43 \pm 16$ & 0 & 0 & 0 \\
\hline CLN-1314 & 100 & 100 & $157 \pm 26$ & $95 \pm 36$ & $58 \pm 20$ & $12 \pm 6$ & $123 \pm 27$ & $1 \pm 1$ & 0 & 0 \\
\hline
\end{tabular}

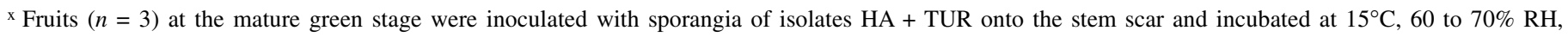
12/light day for 20 days.

y Visual estimation of percent surface area blighted of whole fruits (external) and relative area (percentage) of necrosis in fruits cut median longitudinally.

${ }^{\mathrm{z}}$ Values are mean number of oospores in nine pieces of tissue $(\approx 5 \times 5 \mathrm{~mm})$. 
of seed production, which include washing, drying, disinfection, and coating, will be effective against oospores present in the seed. A previous study showed that fermentation followed by drying of the seeds for $72 \mathrm{~h}$ was effective in controlling mycelia of Phytophthora infestans present in tomato seeds (32). Oospores are longlasting structures that might resist such procedures and therefore may impose a serious threat to the tomato industry. More work is needed to elucidate if oospores in tomato seed can cause infection of the emerging seedling or of neighboring plants.

\section{ACKNOWLEDGMENTS}

This research was supported by Syngenta (Novartis) Crop Protection, Stein, Switzerland. We thank U. Gisi for useful discussions.

\section{LITERATURE CITED}

1. Andrivon, D. 1995. Biology, ecology and epidemiology of the potato late blight pathogen Phytophthora infestans in soil. Phytopathology 85: 1053-1056.

2. Cohen, Y., Farkash, S., Baider, A., and Shaw, D. S. 2000. Sprinkling irrigation enhances production of oospores of Phytophthora infestans in field-grown crops of potato. Phytopathology 90:1105-1111.

3. Cohen, Y., Farkash, S., Reshit, Z., and Baider, A. 1997. Oospore production of Phytophthora infestans in potato and tomato leaves. Phytopathology 87:191-196.

4. Cohen, Y., and Sackston, W. E. 1974. Seed infection and latent infection of sunflower by Plasmopara halstedii. Can. J. Bot. 52:231-238.

5. Day, J. P., and Shattock, R. C. 1997. Aggressiveness and other factors relating to displacement of populations of Phytophthora infestans in England and Wales. Eur. J. Plant Pathol. 103:379-391.

6. Dixon, G. R. 1981. Downy mildews of peas and beans. Pages 487-514 in: The Downy Mildews. D. M. Spencer, ed. Academic Press, London.

7. Drenth, A., Janssen, E. M., and Govers, F. 1995. Formation and survival of oospores of Phytophthora infestans under natural conditions. Plant Pathol. 44:86-94.

8. Dunleavy, J. M. 1981. Downy mildew of soybean. Pages 515-529 in: The Downy Mildews. D. M. Spencer, ed. Academic Press, New York.

9. Esau, K. 1965. The seed. Pages 607-626 in: Plant Anatomy. John Wiley \& Sons Inc., New York.

10. Fry, W. E., Goodwin, S. B., Dyer, A. T., Matuszak, J. M., Drenth, A., Tooley, P. W., Sujkowski, L. S., Koh, Y. J., Cohen, B. A., Spielman, L. J., Deahl, K. L., Inglis, D. A., and Sandlan, K. P. 1993. Historical and recent migrations of Phytophthora infestans: Chronology, pathways, and implications. Plant Dis. 77:653-661.

11. Fry, W. E., Goodwin, S. B., Matuszak, J. M., Spielman, L. J., Milgroom, M. G., and Drenth, A. 1992. Population genetics and intercontinental migrations of Phytophthora infestans. Annu. Rev. Phytopathol. 30:107-129.

12. Gavino, P. D., Smart, C. D., Sandrock, R. W., Miller, J. S., Hamm, P. B., Lee, T. Y., Davis, R. M., and Fry, W. E. 2000. Implications of sexual reproduction for Phytophthora infestans in the United States: Generation of an aggressive lineage. Plant Dis. 84:731-735.

13. Gisi, U., and Cohen, Y. 1996. Resistance to phenylamide fungicides: A case study with Phytophthora infestans involving mating type and race structure. Annu. Rev. Phytopathol. 34:549-572.
14. Goodwin, S. B., Cohen, B. A., and Fry, W. E. 1994. Panglobal distribution of a single clonal lineage of the Irish potato famine fungus. Proc. Natl. Acad. Sci. USA 91:11591-11595.

15. Grierson, D., and Kadar, A. A. 1986. Fruit ripening and quality. Pages 280-296 in: The Tomato Crop. J. A. Atherton and J. Rudich, eds. Chapman and Hall, London.

16. Ho, L. C., and Hewitt, J. D. 1986. Fruit development. Pages 201-240 in: The Tomato Crop. J. A. Atherton and J. Rudich, eds. Chapman and Hall, London.

17. Jaime-Garcia, R., Trinidad-Correa, R., Felix-Gastelum, R., Orum, T. V., Wasmann, C. C., and Nelson, M. R. 2000. Temporal and spatial patterns of genetic structure of Phytophthora infestans from tomato and potato in the Del Fuerte Valley. Phytopathology 90:1188-1195.

18. Kadish, D., and Cohen, Y. 1988. Estimation of metalaxyl resistance in Phytophthora infestans. Phytopathology 78:915-919.

19. Kadish, D., Grinberger, M., and Cohen, Y. 1990. Fitness of metalaxylsensitive and metalaxyl-resistant isolates of Phytophthora infestans on susceptible and resistant potato cultivars. Phytopathology 80:200-205.

20. Lebreton, L., and Andrivon, D. 1998. French isolates of Phytophthora infestans from potato and tomato differ in phenotype and genotype. Eur. J. Plant Pathol. 104:583-594.

21. Lebreton, L., Laurent, C., and Andrivon, D. 1998. Evolution of Phytophthora infestans populations in the two most important potato production areas of France during 1992-96. Plant Pathol. 47:427-439.

22. Lebreton, L., Lucas, J. M., and Andrivon, D. 1999. Aggressiveness and competitive fitness of Phytophthora infestans isolates collected from potato and tomato in France. Phytopathology 89:679-686.

23. Legard, D. E., Lee, T. Y., and Fry, W. E. 1995. Pathogenic specialization in Phytophthora infestans: Aggressiveness on tomato. Phytopathology 85:1356-1361

24. Levin, A., Baider, A., Rubin, E., Gisi, U., and Cohen, Y. 2001. Oospore formation by Phytophthora infestans in potato tubers. Phytopathology 91:579-585.

25. Mayton, H., Smart, C. D., Moravec, B. C., Mizubuti, E. S. G., Muldoon, A. E., and Fry, W. E. 2000. Oospore survival and pathogenicity of single oospore recombinant progeny from a cross involving US-17 and US-8 genotypes of Phytophthora infestans. Plant Dis. 84:1190-1196.

26. Medina, M. V., and Platt (Bud), H. W. 1999. Viability of oospores of Phytophthora infestans under field conditions in northeastern North America. Can. J. Plant Pathol. 21:137-143.

27. Medina, M. V., Platt (Bud), H. W., and Peters, R. D. 2000. Response of tubers of five potato cultivars to co-inoculation with US-1 and US-8 genotypes of Phytophthora infestans. Potato Res. 43:153-161.

28. Miller, J. S., and Johnson, D. A. 2000. Competitive fitness of Phytophthora infestans isolates under semiarid field conditions. Phytopathology 90:220-227.

29. Smirnov, A. N., and Elansky, S. N. 1999. Oospore formation in the field population of Phytophthora infestans in Moscow region. (in Russian with English summary). Mycol. Phytopathol. 33:421-429.

30. Turkensteen, L. J., Flier, W. G., Wanningen, R., and Mulder, A. 2000. Production, survival and infectivity of oospores of Phytophthora infestans. Plant Pathol. 49:688-696.

31. Vartanian, V. G., and Endo, R. M. 1985. Overwintering hosts, compatibility types, and races of Phytophthora infestans on tomato in Southern California. Plant Dis. 69:516-519.

32. Vartanian, V. G., and Endo, R. M. 1985. Survival of Phytophthora infestans in seeds extracted from infected tomato fruits. Phytopathology 75:375-378. 